\title{
Quantifying tidal contribution to submarine groundwater discharges: A review
}

\author{
LI HaiLong ${ }^{1,2^{*}} \&$ JIAO JiuJimmy ${ }^{3}$ \\ ${ }^{1}$ State Key Laboratory of Biogeology and Environmental Geology and School of Water Resources and Environmental Science, China University \\ of Geosciences, Beijing 100083, China; \\ ${ }^{2}$ MOE Key Laboratory of Groundwater Circulation \& Environment Evolution, China University of Geosciences-Beijing, Beijing 100083, China; \\ ${ }^{3}$ Department of Earth Sciences, The University of Hong Kong, Hong Kong, China
}

Received November 15, 2012; accepted May 15, 2013; published online July 31, 2013

\begin{abstract}
Submarine groundwater discharges (SGD), consisting of groundwater flow from both terrestrial and marine origins, is an important source of nutrients, contaminants, and other chemicals to the coastal waters, and has significant impacts and implications on coastal environment and ecology. This paper reviews the recent advances in quantifying the tide-induced SGD in various beach aquifers around the world by means of mathematical modeling, laboratory experiments, and field observations or their combinations. Numerous studies have shown that (1) the order of magnitude of SGD around the world estimated by radium isotope tracers typically ranges from $10^{2}$ to $10^{3} \mathrm{~m}^{3} \mathrm{~d}^{-1} \mathrm{~m}^{-1}$ of the shoreline, (2) SGD is mainly of marine origin, i.e. the re-circulated seawater across the aquifer-sea interface, and (3) tide is one of the major forces driving seawater-groundwater circulation. The order of magnitude of the tidal contributions to SGD from beach aquifers reported in the literature is only $10 \mathrm{~m}^{3} \mathrm{~d}^{-1} \mathrm{~m}^{-1}$ length of shoreline, at least one order of magnitude smaller than the total SGD estimated by radium isotope tracers. This is obviously in contradiction with (3). The possible reasons for this contradiction may include (1) underestimation of the shoreline length due to neglecting many headlands, bays and banks of tidal rivers, and (2) negligence of the seawater-groundwater exchange from the seabed ranging from the nearshore areas to the continental shelf. Further research is needed to understand more about the contradiction.
\end{abstract}

submarine groundwater discharges (SGD), radium isotope tracer method, numerical model of beach aquifer, densitydependent flow, tide-induced SGD

Citation: Li H L, Jiao J J. Quantifying tidal contribution to submarine groundwater discharges: A review. Chin Sci Bull, 2013, 58: 3053-3059, doi: 10.1007/ s11434-013-5951-7

Submarine groundwater discharge (SGD) is defined as any and all flow of water on continental margins from the seabed to the coastal ocean, regardless of fluid composition or driving force [1]. Basically, SGD is composed of the terrestrial freshwater and circulated seawater driven by various forces. The driving forces of SGD can be classified into three groups: (1) terrestrial hydraulic gradients, (2) sea level variations and (3) density gradients (e.g. density difference between the groundwater and seawater induced by salinity or temperature gradients). The terrestrial driving force of SGD is determined by the inland hydraulic gradients in the

\footnotetext{
*Corresponding author (email: hailongli@cugb.edu.cn)
}

coastal aquifers which may have both temporal and spatial variations. The marine driving forces of SGD include various sea level variations such as tides [2-11], waves [12-14], and storms [15-17], etc. The differences in salinity and temperature between seawater and groundwater may cause significant pore water density gradients in coastal aquifers which may in turn result in seawater-groundwater circulation [6,18-22]. Besides the above-mentioned three main SGD driving forces, Santos et al. [23] also discussed several other SGD driving forces such as ripple and other bed form migration, fluid shear, bioirrigation and bioturbation, gas bubble upwelling, and sediment compaction.

Although SGD has been driven by many temporally and 
spatially overlapped terrestrial/oceanic forces, the total SGD at large scales can be evaluated quantitatively using natural radium [24-27] or radon [28-33] as tracers of groundwater discharge to coastal waters. The typical values of SGD estimated around the world range from $10^{2} \mathrm{~m}^{3}$ to $10^{3} \mathrm{~m}^{3} \mathrm{~d}^{-1}$ $\mathrm{m}^{-1}$ length of shorelines, which will be expressed as " $\mathrm{m}^{2} / \mathrm{d}$ " hereafter. For example, Moore estimated that SGD along the southeastern US coast is about $100-300 \mathrm{~m}^{2} / \mathrm{d}$ [24,34], and about $1000 \mathrm{~m}^{2} / \mathrm{d}$ [35] along the coast of Sicily/ Mediterranean; Liu et al. [25] estimated that SGD along the $308 \mathrm{~km}$ coastline east of the Pearl River Estuary ranges from 1104 to $1201 \mathrm{~m}^{2} / \mathrm{d}$.

A major part of SGD is of marine origin, i.e., seawater-groundwater circulation across the aquifer-sea interface $[4,24,36-38]$. During the circulation of seawater, seawater mixes with the terrestrially-derived groundwater and chemicals, leading to various biogeochemical interactions in the pore water in rocks and soils. Therefore, SGD is an important source of nutrients, contaminants, chemicals and trace elements to the coastal waters $[1,24,38-40]$ and has considerable impact on the quality and the ecosystem of the receiving seawater [41-44].

Although groundwater seepage into the oceans occurs in many environments and there has been an explosion of the SGD literature in the past 10 years [45], SGD studies have been carried out in the relatively wealthy regions of the world and those from South America, Africa, India, or China are still very limited $[30,46,47]$. SGD originates from coastal aquifers and then enters the coastal seawater. SGD is a field rooted in hydrogeology, but so far this field has been dominated by oceanographers, while hydrogeologists are not well represented in SGD studies [48]. Hydrogeologists can improve SGD studies by quantitative analysis of groundwater flow dynamics in coastal aquifers. This complements the current, mainly tracers-orientated studies adopted by oceanographers, who tend to focus on the SGD at the surface, i.e. after entering seawater. The involvement of hydrogeologists would lead to a more complete picture of subsurface flow conditions and the effect of this flow field on coastal processes [45,48]. Tide-induced groundwater flow is considered to be one of the major components of SGD [4]. Based on these considerations, this paper reviews the work on quantifying tidal contributions to SGD by hydrogeologists with emphasis on mathematical modeling combined with field and laboratory observations. We hope that our efforts may help both hydrogeologists and oceanographers to exchange their ideas and results in the study of SGD.

\section{Tidal effects on salinity distributions in coastal aquifers}

For coastal aquifers, salinity distribution determined by the pore water density-gradients and dispersion is an issue as important as groundwater hydraulics and has been studied by many researchers. As early as the beginning of last century, Ghyben [51] and Herzberg [52] proposed the wellknown Ghyben-Herzberg approximation of the freshwater-saltwater interface, which states that under hydrostatic condition, if the seawater density is greater than that of freshwater by a percentage of $2.5 \%$ (or $1 / 40$ ), the freshwater-saltwater interface depth below mean sea level is 40 times the water table elevation above sea level.

Cooper [18] showed that the freshwater-saltwater interface is actually a dispersion zone where the water salinity gradually changes from freshwater on the landward side to seawater on the seaward side. The existence of this dispersion zone causes a perpetual seawater-groundwater circulation from the floor of the sea to the dispersion zone and back to the sea. Glover [53] presented a more realistic analytical expression of the freshwater-saltwater interface which takes into account the freshwater recharge, the aquifer's hydraulic conductivity and the density difference between the seawater and freshwater.

Ataie-Ashtiani et al. [2] simulated the tidal effects on sea water intrusion in unconfined aquifers using numerical model modified from SUTRA [54]. They showed that the tidal activity forces the sea-water to intrude further inland and it also creates a thicker dispersion zone than would occur without tidal effects. Boufadel [55] conducted laboratory experiments and numerical simulations to investigate the effects of tides and buoyancy on beach hydraulics. Two distinct salt plumes were observed: the classical saltwater wedge described by Cooper [18] and a new saline plume "hanging" immediately beneath the beach surface. Between these two plumes forms a freshwater discharge path, through which fresh groundwater discharges near the low tide mark. This actually explains the field observations that the major portion of the seaward groundwater seepage usually occurs in the shallow part of the submerged beach [56-60]. The salt plume hanging beneath the beach surface forms a small scale seawater-groundwater circulation: seawater infiltrates into the beach in the upper intertidal zone and exits near the low tide mark. This typical salinity structure of two-plume sandwiched freshwater discharge path was confirmed by many other recent studies including laboratory experiments [5,61], field observations [62,63], numerical simulations $[6,7,64,65]$ and combinations of experiments and numerical simulations $[7,8,40,49,50,66,67]$.

For aquifers with sufficiently small freshwater discharge rate and/or depth, the freshwater discharge path may disappear and the two plumes merge into one, the scenario considered by Ataie-Ashtiani et al. [2] or by Li et al. [8]. In the extreme case of very large freshwater recharge from inland, the upper, the tide-induced salt plume may be very small or disappear, as was shown by the laboratory experiment and numerical simulation of Zhang et al. [68], Volk et al. [69], and Brovelli et al. [70]. The tide-induced salt plume can be very thin and significantly dynamic with respect to tidal 
variations in gravel beaches where a surface layer much more permeable than the lower layer exists $[9,11,71,72]$.

These studies contributed significantly to the fast advances in quantifying the relationship among the salinity structure, the inland freshwater recharge, the density effect and the tidal actions in coastal aquifers.

\section{Mechanism of the tide-induced SGD and challenges in quantifying it}

The mechanism of the tide-induced SGD is simple: the seawater enters the sea-land interface during rising and high tides and leaves the interface during falling and low tides $[3,7,8,32,49,50]$. However, it is very difficult to quantify this process in various coastal aquifer systems due to the nonlinearity and complexity caused by various factors such as density difference between seawater and freshwater, the spring-neap variation of the tidal fluctuations, heterogeneity and anisotropy of the aquifer, the beach slope or topography, capillary effects and variable-saturation in the vadose zone, seepage face, disturbance of animals and plants, pore water dispersions, spatial and temporal variations in inland recharge, etc.

In order to investigate which of these factors have been considered in the literature studying the tide-induced seawater-groundwater interaction in the intertidal zone, a summary is given in Table 1 for some representative publications. All of them are two-dimensional vertical crosssectional models. Most of them are numerical simulations of the field data. Various numerical codes were used such as SEAWAT, MARUN, SUTRA, and COMSOL. One can see that even the widely-used numerical code SEAWAT has its own weakness because it does not simulate seepage face and unsaturated flow. On the other hand, although the numerical code MARUN can simulate seepage face and unsaturated flow, it has no graphical input/output interfaces. It is therefore an urgent task and great challenge for hydrogeologists to develop a density-dependent groundwater flow code which is not only able to efficiently deal with the above-mentioned nonlinearities and complexities, but also has friendly graphical output and input interfaces.

\section{Tide-induced SGD from beach aquifers}

Although there are numerous publications related to the analytical and numerical studies of tide-induced seawater-groundwater circulations, many of them did not explicitly address the issue of SGD (Table 1). In this section, only the studies that explicitly reported the tidal contributions to SGD will be reviewed in a chronological order. Most of these studies are based on numerical models and simulations, and only a few are based on analytical studies $[3,73,74]$.
In 1999, Robinson and Gallagher [75] did the first work to quantify the SGD in the intertidal zone using a density-dependent, variably-saturation numerical model with comparison to field observations of the water table, salinity and measured discharge rate. However, they did not report the total SGD in the intertidal zone.

In 2003, Li and Jiao [3] quantified tidal contributions to SGD in a multi-layered coastal aquifer system with vertical sea-land interface using a simplified analytical model ignoring density-effect. They concluded that part of the seawater entering the unconfined aquifer may leak into the underlying confined aquifer and then return to the sea. The tide-induced SGD through the confined aquifer is significant $\left(0.38-1.06 \mathrm{~m}^{2} / \mathrm{d}\right)$ when tidal amplitude is $1 \mathrm{~m}$, the dimensionless leakage ranges from 0.005 to 0.05 and transmissivities of the confined and unconfined aquifers equal 50 $\mathrm{m}^{2} / \mathrm{d}$. Chuang et al. [73] refined the results of Li and Jiao [3] in 2012. For a coastal leaky aquifer system when tidal amplitude is $1 \mathrm{~m}$, leakance is $0.051 / \mathrm{d}$ and transmissivities of the confined and unconfined aquifers equal $2000 \mathrm{~m}^{2} / \mathrm{d}$, the tide-induced SGD is $23.0 \mathrm{~m}^{2} / \mathrm{d}$, among which, $20.0 \mathrm{~m} / \mathrm{d}$ through the unconfined aquifer, and $3.0 \mathrm{~m}^{2} / \mathrm{d}$ through the confined aquifer.

In 2005, Prieto and Destouni [76] simulated three very deep coastal aquifers $(50-150 \mathrm{~m})$ subjected to diurnal tide with amplitude of $0.65 \mathrm{~m}$ using the numerical model SUTRA [54] and obtained a maximum tidal contribution to SGD of about $2000 \mathrm{~m}^{2} / \mathrm{a}\left(5.48 \mathrm{~m}^{2} / \mathrm{d}\right)$.

In 2007, Robinson, Li and Barry [6] made comprehensive analyses for tidal contributions in a hypothetical homogenous coastal aquifer using the numerical model SEAWAT 2000 [77]. They concluded that the tide-driven SGD is comparable to the density-driven SGD for several aquifer systems with typical hydrogeological parameter values. Robinson et al. [7] used the same numerical model and found that significant tide-driven SGD is expected when the ratio of tidal to inland forcing is large. Their numerical simulations using typical coastal aquifer parameters give a tide-induced SGD value ranging from about 0.5 to $8.5 \mathrm{~m}^{2} / \mathrm{d}$ (Figure $8 \mathrm{~b}$ of their paper). The analysis also indicates that tidal effects increase density-driven seawater-groundwater circulation rates due to enhanced convective flow within the saltwater wedge. Robinson et al. [50] used the same numerical model to simulate salt-freshwater dynamics in a subterranean estuary during the whole spring-neap tidal cycle, and they obtain an estimation of 3.3 $\mathrm{m}^{2} / \mathrm{d}$ for the tidal contribution to SGD during spring tides, and $2.2 \mathrm{~m}^{2} / \mathrm{d}$ during the neap tides.

In 2008, Li et al. [8] investigated the tide-induced seawater-groundwater circulation in shallow, homogeneous and isotropic beach aquifers using a dimensionless formulation of the finite element model MARUN [78]. Numerical simulation results in one nondimensionalized coastal aquifer with fixed beach slope of $10 \%$, dimensionless tidal amplitude of 1 were applied to analyze tidal contributions to 


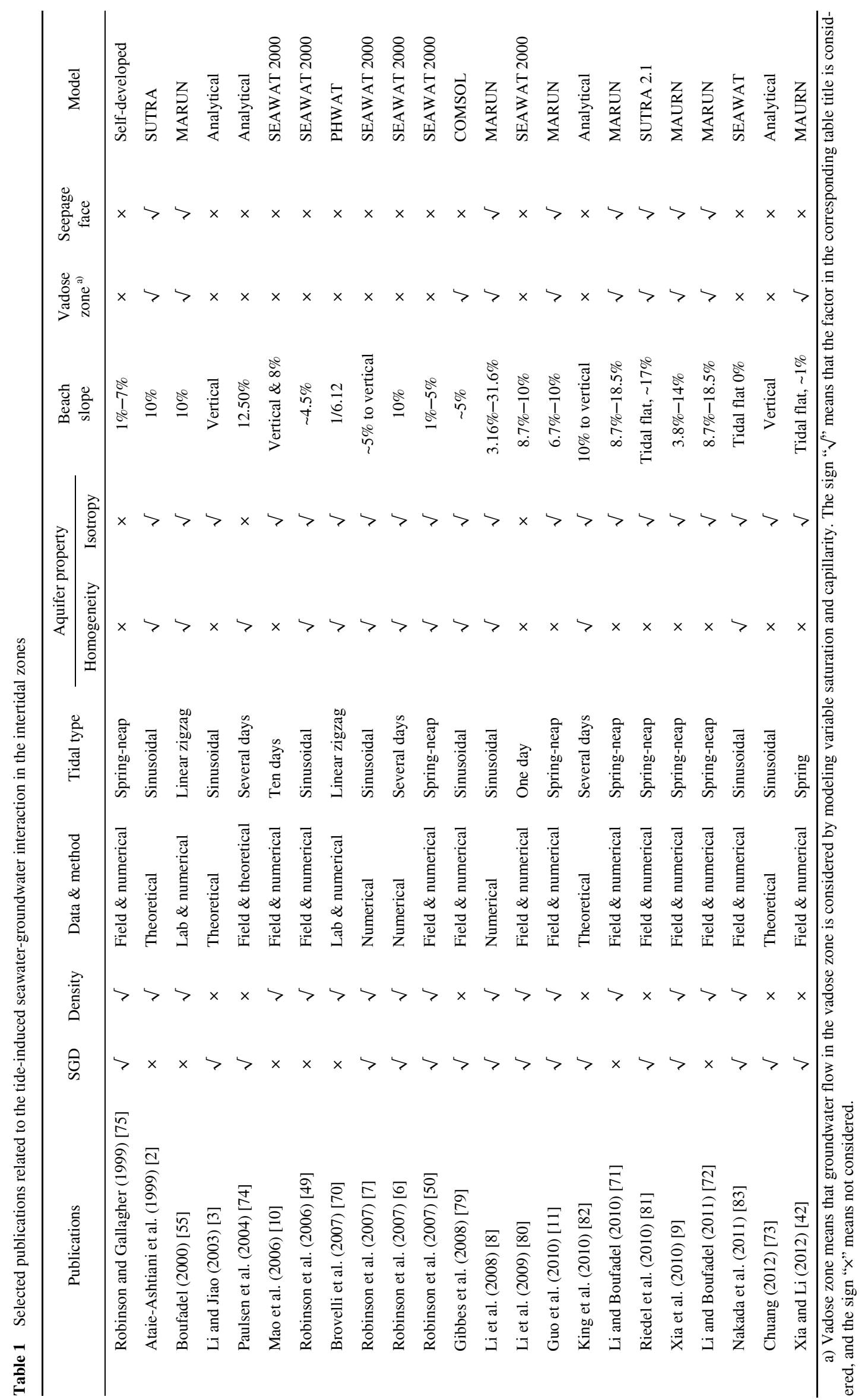


SGD in various beaches with different hydraulic conductivities $\left(10^{-4}-10^{-3} \mathrm{~m} / \mathrm{s}\right)$, different beach slopes $(3.16 \%-$ $31.6 \%)$, different tidal amplitudes $(0.3-2 \mathrm{~m})$ and different tidal periods (diurnal or semidiurnal). They found that the tidal contributions to SGD increase with the tidal amplitude, beach hydraulic conductivity and decrease as the terrestrial inland recharge increases. In most cases the tidal contributions to SGD increase with the beach slope. The maximum tidal contributions to SGD per tidal cycle range from 0.23 $A^{* 2}$ to $3.28 A^{* 2}$ for all different values of the beach slope, tidal amplitude $A^{*}$, and beach hydraulic conductivity. For example, for semidiurnal tides with amplitude of $1.0 \mathrm{~m}$, the maximum tidal contributions to SGD per tidal cycle can be as large as $3.28 \mathrm{~m}^{2}$ per tidal cycle or about $6.5 \mathrm{~m}^{2} / \mathrm{d}$. Based on field observations, Colbert et al. [32] obtained an estimation of $1.0 \pm 0.3 \mathrm{~m}^{2} / \mathrm{d}$ for the tidal contribution in a beach at the head of Catalina Harbor, CA. Using the given beach slope of 0.045 and the diurnal tidal amplitude of about $0.8 \mathrm{~m}$, the numerical simulation results of Li et al. [8] ranges from 0.192 to $1.472 \mathrm{~m}^{2} / \mathrm{d}$ when the hydraulic conductivity increases from 5.5 to $55 \mathrm{~m} / \mathrm{d}$, which gives a reasonable estimation of the tide-induced seawater-groundwater circulation and beach hydraulic conductivity. Gibbes et al. [79] simulated the observed tide-induced water table fluctuations in an intertidal sandbank in Moreton Bay, Australia and obtained an estimation of tide-induced SGD of $1.626 \mathrm{~m}^{2} / \mathrm{d}$.

In 2009, Li et al. [80] simulated the seawater-groundwater interactions in a coastal unconfined aquifer in the northeastern Gulf of Mexico using the numerical code SEAWAT2000. They obtained the quantitative estimations of tidal contributions of SGD of 16 cases under different tidal ranges and inland watertables, which ranges from 2.19 to $4.41 \mathrm{~m}^{2} / \mathrm{d}$.

In 2010, Xia et al. [9] used the numerical model MARUN [78] reproduced the field observed watertable, pore water salinity and lithium tracer concentration accurately in a two-layered gravel beach in Knight Island, Prince William Sound, Alaska. The tidal contribution to SGD over a spring-neap tidal cycle was about $2.1 \mathrm{~m}^{2} / \mathrm{d}$. Guo et al. [11] obtained an estimation of about $9 \mathrm{~m}^{2} / \mathrm{d}$ used the same numerical model in another heterogeneous gravel beach near that of Xia et al. [9]. The tidal range in the area is about 4.6 $\mathrm{m}$. The difference between these two estimates is mainly due to the fact that one-third of the intertidal zone of the gravel beach studied by Xia et al. [9] is vertical impermeable bedrock cliff.

In the same year, Riedel et al. [81] simulated the water table fluctuations at a well-studied tidal flat margin in the German Wadden Sea using the numerical model SUTRA. They obtained the values of tidal contribution to SGD over 12 months with the average and maximum being $0.97 \mathrm{~m}^{3}$ and $1.59 \mathrm{~m}^{3} \mathrm{~m}^{-1}$ of shoreline length per tide, respectively (or equivalently, about 1.9 and $3.2 \mathrm{~m}^{2} / \mathrm{d}$, respectively). King et al. [82] used analytical models for the groundwater tidal prism to obtain an estimate of the tidal contribution of SGD of $21.6 \mathrm{~m}^{2} / \mathrm{d}$ for a region of the South Atlantic Bight.

In 2011, Nakada et al. [83] used the numerical model SEAWAT 2000 to describe the hydrogeology in a tidal flat and adjacent sea water. From their simulated spatial distribution of SGD (Figure 6(a) and (c)) the tidal contribution to SGD can be estimated to be $\sim 20 \mathrm{~m}^{2} / \mathrm{d}$.

In 2012, Xia and $\mathrm{Li}$ [42] used the numerical model MARUN reproduced the field observed watertable in two transects (one is mangrove transect and the other is tidal flat) in mangrove marshes in Dongzhaigang National Nature Reserve, Hainan, China. They identified that both transects have a mud-sand two-layered structure: a surface zone of low-permeability mud and an underlying high permeability zone that outcrops at the high and low tide lines. Seawater infiltrated the high-permeability zone through its outcrop near the high intertidal zone, and discharged from the tidal river bank in the vicinity of the low tide line. The simulated tidal contribution to SGD was $2.15 \mathrm{~m}^{2} / \mathrm{d}$ for the mangrove transect and $6.0 \mathrm{~m}^{2} / \mathrm{d}$ for the tidal flat transect. Considering that most of the tidal rivers in estuaries are winding and have very long banks, these processes may provide considerable contribution to the total submarine groundwater discharge.

\section{Summary and future work}

In summary, it is an urgent task and great challenge for hydrogeologists to develop a groundwater flow code which not only has friendly graphical output and input interfaces, but also is able to efficiently deal with the nonlinearities and complexities in modeling groundwater influenced by seawater such as density difference between seawater and freshwater, the spring-neap variation of the tidal fluctuations, heterogeneity and anisotropy of the aquifer, the beach slope or topography, capillary effects and variable-saturation in the vadose zone, seepage face, disturbance of animals and plants, pore water dispersions, spatial and temporal variations in inland recharge, etc. Tidal contributions to SGD from beach aquifers are less than $10 \mathrm{~m}^{2} / \mathrm{d}$ for most of the above-mentioned studies, with the minimum being 0.5 $\mathrm{m}^{2} / \mathrm{d}$, maximum being $23 \mathrm{~m}^{2} / \mathrm{d}$ and the average only being $11.8 \mathrm{~m}^{2} / \mathrm{d}$, much smaller than the typical value range of the total SGD around the world $\left(10^{2}-10^{3} \mathrm{~m}^{2} / \mathrm{d}\right)$ obtained by the Radium isotope methods. This is obviously in contradiction with the common sense that tide is one of the major forces driving seawater-groundwater circulation. The future research may focus on the possible reasons for this contradiction, which may at least include the following.

(1) When $\mathrm{Ra}$ isotope methods were used to estimate the SGD per unit length of the shoreline, the length of the coastline might be significantly underestimated by neglecting many headlands, banks of tidal rivers and bays in different scales along the shoreline. A proper re-evaluation of the shoreline length in a scale resolution comparable to the 
intertidal zone is necessary in order to include the tide-induced SGD in various headlands, bays and banks of tidal rivers. Such a re-evaluation may produce a much longer coastline length which decreases significantly the current estimation of SGD per unit length of the shoreline.

(2) When the Radium isotope methods were used to estimate the total SGD, the cross-shore width of the considered coastal area is very large (hundreds of kilometers of the whole seabed of the continental shelf). The tidal contribution to SGD considered here is only limited near the intertidal zone (i.e. the tide-induced seawater-groundwater circulation in the unconfined beach aquifer), which only has a cross-shore width ranging from tens of meters to several kilometers. In reality, however, seawater may be "pushed" into the seabed sediments during rising and high tides and released from seabed sediments during falling and low tides due to the elastic compression and expansion of the seawater, which corresponds to the seawater-groundwater circulation in the confined aquifer. Although this kind of flux is small, it occurs in a much greater area (the whole seabed of the continental shelf) and may have considerable contributions to SGD.

This work was supported by the Outstanding Young Scientists of the National Natural Science Foundation of China (41025009) and the Research Grants Council of Hong Kong (HKU702611). We thank the editor and reviewers for their helpful revisions.

1 Burnett W C, Bokuniewicz H, Huettel M, et al. Groundwater and pore water inputs to the coastal zone. Biogeochemistry, 2003, 66: 3-33

2 Ataie-Ashtiani B, Volker R E, Lockington D A. Tidal effects on sea water intrusion in unconfined aquifers. J Hydrol, 1999, 216: 17-31

3 Li H, Jiao J J. Tide-induced seawater-groundwater circulation in a multi-layered coastal leaky aquifer system. J Hydrol, 2003, 274: 211224

4 Li L, Barry D A, Stagnitti F, et al. Submarine groundwater discharge and associated chemical input to a coastal sea. Water Resour Res, 1999, 35: 3252-3259

5 Mango A J, Schmeeckle M W, Furbish D J. Tidally induced groundwater circulation in an unconfined coastal aquifer modeled with a Hele-Shaw cell. Geology, 2004, 32: 233-236

6 Robinson C, Li L, Barry D. Effect of tidal forcing on a subterranean estuary. Adv Water Resour, 2007, 30: 851-865

7 Robinson C, Li L, Prommer H. Tide-induced recirculation across the aquifer-ocean interface. Water Resour Res, 2007, 43: W07428

$8 \mathrm{Li} \mathrm{H} \mathrm{L,} \mathrm{Boufadel} \mathrm{M} \mathrm{C,} \mathrm{Weaver} \mathrm{J} \mathrm{W.} \mathrm{Tide} \mathrm{induced} \mathrm{seawater-}$ groundwater circulation in shallow beach aquifer. J Hydrol, 2008, 352: 211-224

9 Xia Y Q, Li H, Boufadel M C, et al. Hydrodynamic factors affecting the persistence of the Exxon Valdez oil in a shallow bedrock beach. Water Resour Res, 2010, 46: W10528

10 Mao X, Enot P, Barry D A, et al. Tidal influence on behaviour of a coastal aquifer adjacent to a low-relief estuary. J Hydrol, 2006, 327: $110-127$

11 Guo Q, Li H, Boufadel M C, et al. Hydrodynamics in a gravel beach and its impact on the Exxon Valdez oil. J Geophys Res-Oceans, 2010, 115: C12077

12 Xin P, Robinson C, Li L, et al. Effects of wave forcing on a subterranean estuary. Water Resour Res, 2010, 46: W12505

13 Li L, Barry D A. Wave-induced beach groundwater flow. Adv Water
Resour, 2000, 23: 325-337

14 Longuet-Higgins M S. Wave set-up, percolation and undertow in the surf zone. In: Proceedings of the Royal Society of London. Series A, Mathematical and Physical Sciences. London. 1983

15 Moore W S, Wilson A M. Advective flow through the upper continental shelf driven by storms, buoyancy, and submarine groundwater discharge. Eearth Planet Sci Lett, 2005, 235: 564-576

16 Wilson A M, Moore W S, Joye S B, et al. Storm-driven groundwater flow in a salt marsh. Water Resour Res, 2011, 47: W02535

17 Li L, Cartwright N, Nielsen P, et al. Response of coastal groundwater table to offshore storms. China Ocean Eng, 2004, 18: 423-431

18 Cooper H H. A hypothesis concerning the dynamic balance of fresh water and salt water in a coastal aquifer. J Geophys Res, 1959, 64: 461-467

19 Destouni G, Prieto C. On the possibility for generic modelling of submarine groundwater discharge. Biogeochemistry, 2003, 66: 171186

20 Wilson A M. Fresh and saline groundwater discharge to the ocean: A regional perspective. Water Resour Res, 2005, 41: W02016

21 Smith A J. Mixed convection and density-dependent seawater circulation in coastal aquifers. Water Resour Res, 2004, 40: W08309

22 Kaleris V. Submarine groundwater discharge: Effects of hydrogeology and of near shore surface water bodies. J Hydrol, 2006, 325: 96-117

23 Santos I R, Eyre B D, Huettel M. The driving forces of porewater and groundwater flow in permeable coastal sediments: A review. Estura Coast Shelf S, 2012, 98: 1-15

24 Moore W S. Large groundwater inputs to coastal waters revealed by 226Ra enrichments. Nature, 1996, 380: 612-614

25 Liu Q, Dai M, Chen W, et al. Charette, How significant is submarine groundwater discharge and its associated dissolved inorganic carbon in a river-dominated shelf system? Biogeosciences, 2012, 9: 1777-1795

26 Moore W S. Estimating submarine groundwater discharge in the range (10)1 to (10)8 $\mathrm{km}(2)$ using Ra isotopes. Geochim Cosmochim Acta, 2007, 71: A684-A684

27 Lee C M, Jiao J J, Luo X, et al. Estimation of submarine groundwater discharge and associated nutrient fluxes. In Tolo Harbour, Hong Kong. Sci Total Environ, 2012, 433: 427-433

28 Colbert S L, Hammond D E, Berelson W M. Radon-222 budget in Catalina Harbor, California: 1. Water mixing rates. Limnol Oceanogr, 2008, 53: 651-658

29 Burnett W C, Dulaiova H. Estimating the dynamics of groundwater input into the coastal zone via continuous radon-222 measurements. J Environ Radioactiv, 2003, 69: 21-35

30 Peterson R N, Burnet W C, Taniguchi M, et al. Radon and radium isotope assessment of submarine groundwater discharge in the Yellow River delta, China. J Geophys Res-Oceans, 2008, 113: C09021

31 Cable J E, Burnett W C, Chanton J P, et al. Estimating groundwater discharge into the northeastern Gulf of Mexico using radon-222. Eearth Planet Sc Lett, 1996, 144: 591-604

32 Colbert S L, Berelson W M, Hammond D E. Radon-222 budget in Catalina Harbor, California: 2. Flow dynamics and residence time in a tidal beach. Limnol Oceanogr, 2008, 53: 659-665

33 Tse K C, Jiao J J. Estimation of submarine groundwater discharge in Plover Cove, Tolo Harbour, Hong Kong by Rn-222. Mar Chem, 2008, 111: $160-170$

34 Moore W S. A reevaluation of submarine groundwater discharge along the southeastern coast of North America. Glob Biogeochem Cycle, 2010, 24: Gb4005

35 Moore W S. Radium isotopes as tracers of submarine groundwater discharge in Sicily. Cont Shelf Res, 2006, 26: 852-861

36 Younger P. Submarine groundwater discharge. Nature, 1996, 382: 121-122

37 Moore W S, Church T M. Submarine groundwater discharge - Reply. Nature, 1996, 382: 122

38 Church T. An underground route for the water cycle. Nature, 1996, 380: $579-580$

39 Simmons G M. Importance of submarine groundwater discharge (SGWD) and seawater cycling to material flux across the sedi- 
ment/water interfaces in marine environments. Mar Ecol Prog Ser, 1992, 84: 173-184

40 Michael H A, Mulligan A E, Harvey C F. Seasonal oscillations in water exchange between aquifers and the coastal ocean. Nature, 2005, 436: 1145-1148

41 Paytan A, Shellenbarger G G, Street J H, et al. Submarine groundwater discharge: An important source of new inorganic nitrogen to coral reef ecosystems. Limnol Oceanogr, 2006, 51: 343-348

42 Xia Y Q, Li H L. A combined field and modeling study of groundwater flow in a tidal marsh. Hydrol Earth Syst Sci, 2012, 16: 741-759

43 Peterson C H, Rice S D, Short J W, et al. Long-term ecosystem response to the Exxon Valdez oil spill. Science, 2003, 302: 2082-2086

44 Johannes R. The ecological significance of the submarine discharge of groundwater. Mar Ecol Prog Ser, 1980, 3: 365-373

45 Moore W S. The Effect of Submarine Groundwater Discharge on the Ocean. Annu Rev Mar Sci, 2010, 2: 59-88

46 Kim G, Ryu J W, Yang H S, et al. Submarine groundwater discharge (SGD) into the Yellow Sea revealed by Ra-228 and Ra-226 isotopes: Implications for global silicate fluxes. Eearth Planet Sci Lett, 2005, 237: 156-166

47 Taniguchi M, Ishitobi T, Chen J, et al. Submarine groundwater discharge from the Yellow River Delta to the Bohai Sea, China. J Geophys Res-Oceans, 2008, 113: C06025

48 Kazemi G A. Editor's Message: Submarine groundwater discharge studies and the absence of hydrogeologists. Hydrogeol J, 2008, 16: 201-204

49 Robinson C, Gibbes B, Li L. Driving mechanisms for groundwater flow and salt transport in a subterranean estuary. Geophys Res Let, 2006, 33: L03402

50 Robinson C, Gibbes B, Carey H, et al. Salt-freshwater dynamics in a subterranean estuary over a spring-neap tidal cycle. J Geophys Res, 2007, 112: C09007

51 Ghyben WB. Notes in verband met voorgenomen put boring Nabji Amsterdam. Tijdschrift van let koninklijk Institut van Ingeniers, Hague, Netherlands. 1899

52 Herzberg A. Die Wasserversorgung einiger Nordseebder. Zeitshriftfur Gasbeleuchtung und Wasserversorgung, 1901, 44: 815-819

53 Glover R E. The pattern of fresh water flow in coastal aquifers. J Geophys Res, 1959, 64: 439-475

54 Voss C I. SUTRA, A finite-element model for saturated-unsaturated fluid-density-dependent groundwater flow with energy transport or chemically reactive single-species solute transport. USGS WaterResources Investigations Report 84-4369. 409pp. 1984

55 Boufadel M C. A mechanistic study of nonlinear solute transport in a groundwater-surface water system under steady state and transient hydraulic conditions. Water Resour Res, 2000, 36: 2549-2565

56 Bokuniewicz H. Groundwater seepage into Great South Bay, New York. Estura Coast Shelf S, 1980, 10: 437-444

57 Taniguchi M. Tidal effects on submarine groundwater discharge into the ocean. Geophys Res Lett, 2002, 29: 1561

58 Slomp C, Van Capellen P. Nutrient inputs to the coastal ocean through submarine groundwater discharge: Controls and potential impact. J Hydrol, 2004, 295: 64-86

59 Cable J E, Burnett W C, Chanton J P. Magnitude and variations of groundwater seepage along a Florida marine shoreline. Biogeochemistry, 1997, 38: 189-205

60 Taniguchi M, Ishitobi T, Shimata J. Dynamics of submarine groundwater discharge and fresh-seawater interface. J Geophys Res, 2006, 111: $\mathrm{C} 01008$

61 Boufadel M C, Suidan M T, Venosa A D. Tracer studies in a laboratory beach simulating tidal influences. J Environ Eng-ASCE, 2006, 132: 616-623

62 Westbrook S J, Rayner J L, Davis G B, et al. Interaction between shallow groundwater, saline surface water and contaminant discharge at a seasonally and tidally forced estuarine boundary. J Hydrol, 2005, 302: 255-269

63 Turner I L, Acworth R. I. Field measurements of beachface salinity structure using cross-borehole resistivity imaging. J Coast Res, 2004, 20: 753-760

64 Werner A D, Lockington D A. Tidal impacts on riparian salinities near estuaries. J Hydrol, 2006, 328: 511-522

65 Li H L, Zhao Q H, Boufadel M C, et al. A universal nutrient application strategy for the bioremediation of oil polluted beaches. Mar Pollut Bull, 2007, 54: 1146-1161

66 Mao X, Enot P, Barry D A, et al. Tidal influence on behaviour of a coastal aquifer adjacent to a low-relief estuary. J Hydrol, 2006, 327: 110-127

67 Vandenbohede A, Lebbe L. Occurrence of salt water above fresh water in dynamic equilibrium in a coastal groundwater flow system near De Panne, Belgium. Hydrogeology J, 2005, 14: 462-472

68 Zhang Q, Volker R E, Lockington D A. Experimental investigation of contaminant transport in coastal groundwater. Adv Environ Res, 2002, 6: 229-237

69 Volker R E, Zhang Q, Lockington D A. Numerical modelling of contaminant transport in coastal aquifers. Math Compit Simulat, 2002, 59: 35-44

70 Brovelli A, Mao X, Barry D. Numerical modeling of tidal influence on density-dependent contaminant transport. Water Resour Res, 2007, 43: w10426

71 Li H L, Boufadel M C. Long-termpersistence of oil fromthe Exxon Valdez spill in two-layer beaches. Nat Geosci, 2010, 3: 96-99

72 Li H L, Boufadel M C. A tracer study in an Alaskan gravel beach and its implications on the persistence of the Exxon Valdez oil. Mar Pollut Bull, 2011, 62: 1261-1269

73 Chuang M H, Mahdi A A, Yeh H D. A perturbation solution for head fluctuations in a coastal leaky aquifer system considering water table over-height. Hydrologiques Hydrolog Sci J, 2012, 57: 162-172

74 Paulsen R J, O'Rourke D, Smith C F, et al. Tidal load and salt water influences on submarine ground water discharge. Ground Water, 2004, 42: 990-999

75 Robinson M A, Gallagher D L. A model of ground water discharge from an unconfined coastal aquifer. Ground Water, 1999, 37: 80-87

76 Prieto C, Destouni G. Quantifying hydrological and tidal influences on groundwater discharges into coastal waters. Water Resour Res, 2005, 41: W12427

77 Langevin C, Shoemaker W, Guo W. Modflow-2000, The U. S. Geological Survey modular ground-water model-Documentation of the Seawat-2000 version with the variable density flow process (VDF) and the integrated MT3DMS transport process (IMT), USGS Open File Rep, 03-426, 57, 2003

78 Boufadel M C, Suidan M T, Venosa A D. A numerical model for density-and-viscosity-dependent flows in two-dimensional variably-saturated porous media. J Contam Hydrol, 1999, 36: 1-20

79 Gibbes B, Robinson C, Li L, et al. Tidally driven pore water exchange within offshore intertidal sandbanks: Part II numerical simulations. Estura Coast Shelf S, 2008, 79: 121-132

80 Li X, Hu B X, Burnett W C, et al. Submarine Ground Water Discharge Driven by Tidal Pumping in a Heterogeneous Aquifer. Ground Water, 2009, 47: 558-568

81 Riedel T, Lettmann K, Beck M, et al. Tidal variations in groundwater storage and associated discharge from an intertidal coastal aquifer. J Geophys Res-Oceans, 2010, 115: C04013

82 King J N, Mehta A J, Dean R G. Analytical models for the groundwater tidal prism and associated benthic water flux. Hydrogeol J, 2010, 18: 203-215

83 Nakada S, Yasumoto J, Taniguchi M, et al. Submarine groundwater discharge and seawater circulation in a subterranean estuary beneath a tidal flat. Hydrol Process, 2011, 25: 2755-2763

Open Access This article is distributed under the terms of the Creative Commons Attribution License which permits any use, distribution, and reproduction in any medium, provided the original author(s) and source are credited. 